\title{
EKSEKUSI JAMINAN FIDUSIA TERHADAP PEMBIAYAAN BERMASALAH DI KOPERASI BAITUL MAAL WA TAMWIL KABUPATEN SEMARANG
}

\author{
Rahmawan, Mochammad Dja'is \\ Program Studi Magister Kenotariatan, \\ Fakultas Hukum, Universitas Diponegoro
}

\begin{abstract}
The purpose of executing the object of fiduciary is to guarantee the repayment of the credit facility granted by banking institutions as creditors. The problem in this study is on the execution of motor vehicles in the Baitul Maal Tanwil in the district of Semarang cause many problems. This thesis uses normative juridical research method and empirical research data support. Based on qualitative analysis known that prevention fiduciary execution problems, can be done by registration of fiduciary security object at the Ministry of Justice and Human Rights through an online application method, but to do an execution must be done on the spot, online application method of the execution of fiduciary can make sure a justice and legal standing for creditors to execution of fiduciary object, and by registering online fiduciary guarantee object, the object is expected to issue execution fiduciary.
\end{abstract}

Keywords : Fiduciary, Execution Fiduciary, Baitul Maal Tamwil.

\begin{abstract}
Abstrak
Tujuan pelaksanaan eksekusi objek jaminan fidusia adalah untuk menjamin pelunasan terhadap fasilitas kredit yang diberikan oleh lembaga perbankan selaku kreditor. Pelaksanaan eksekusi objek jaminan fidusia pada kendaraan bermotor pada Baitul Maal Tanwil di wilayah Kabupaten Semarang menimbulkan berbagai macam permasalahan. Penulisan tesis ini menggunakan metode penelitian yuridis normatif dan didukung data penelitian empiris. Berdasarkan analisis kualitatif diketahui bahwa pencegahan permasalahan pelaksanaan eksekusi jaminan fidusia, dapat dilakukan dengan melakukan pendaftaran objek jaminan fidusia pada kantor Kementerian Hukum dan Hak Asasi Manusia melalui metode pendaftaran secara online, tetapi pelaksanaan eksekusi jaminan fidusia tetap dilakukan secara langsung di lapangan, pendaftaran objek jaminan fidusia secara online, memberikan suatu kepastian hukum atau legal standing yang jelas bagi kreditor di dalam mengeksekusi objek jaminan fidusia.
\end{abstract}

Kata kunci : Fidusia, Eksekusi Jaminan Fidusia, Baitul Maal Tamwil. 


\section{A. Pendahuluan}

Seiring dengan perkembangan perekonomian nasional yang semakin berkembang pesat, maka semakin banyak lembaga pembiayaan (finance) dan bank (bank umum maupun perkreditan) menyelenggarakan pembiayaan bagi konsumen (consumer finance), sewa guna usaha (leasing) dan berbagai produk perbankan lainnya, mereka umumnya menggunakan tata cara perjanjian yang mengikutkan adanya jaminan fidusia bagi objek benda jaminan fidusia.

Berdasarkan pada ketentuan umum Buku Ketiga Undang-undang Hukum Perdata Pasal 1233 yaitu perikatan lahir karena suatu persetujuan atau karena Undang-undang, maka perjanjian kredit merupakan suatu perjanjian yang bebas dilakukan oleh masyarakat selaku calon debitor dan bank selaku calon kreditor, kebebasan disini memiliki arti bebas dalam menentukan jumlah nilai pinjaman, maupun kebebasan menentukan jangka waktu pengembalian pinjaman, selama hal tersebut tidak melanggar undang-undang dan peraturan yang berlaku, ketertiban umum, serta kesusilaan. Perjanjian itu menimbulkan suatu perikatan antara dua orang yang membuatnya. (Subekti, 2008) Dalam hal ini debitor dan kreditor melakukan perjanjian kredit.

Pada prakteknya lembaga pembiayaan menyediakan barang bergerak yang diminta konsumen (semisal motor atau mesin industri), kemudian diatasnamakan konsumen sebagai debitor (penerima kredit atau pinjaman), konsekuensinya adalah debitor menyerahkan kepada kreditor dengan jaminan fidusia. Pengertian jaminan disini adalah pemberian keyakinan kepada pihak kreditor atas pembayaran utang-utang yang telah diberikannya kepada debitor, dimana hal ini terjadi karena hukum, ataupun terbit suatu perjanjian yang bersifat accesoir, terhadap perjanjian pokoknya yang berupa perjanjian yang menerbitkan hutang piutang. (Fuady, 2013)

Artinya debitor sebagai pemilik atas nama barang menjadi pemberi fidusia kepada kreditor yang dalam posisi sebagai penerima fidusia, praktek sederhana dalam jaminan fidusia adalah debitor atau pihak yang memiliki 
barang mengajukan pembiayaan kepada kreditor, lalu kedua belah pihak samasama sepakat mengunakan fidusia terhadap benda milik debitor dan dibuatkan akta notaris lalu didaftarkan secara daring melalu laman Administrasi Hukum Umum online.

Eksekusi terhadap objek jaminan fidusia dapat dapat dilakukan dengan pelelangan, di mana pengertian lelang adalah penjualan barang yang terbuka untuk umum dengan penawaran harga secara tertulis dan atau lisan, yang semakin meningkat atau menurun untuk mencapai harga tertinggi yang didahului oleh pengumuman lelang.

Tegas dan kakunya proses pelaksanaan ekskusi pada jaminan fidusia yang lebih mengutamakan pelunasan dan keuntungan kreditor, sepihak yaitu hanya menjamin pelunasan pihak kreditor, tentunya bagi sebagian besar masyarakat Indonesia yang mayoritas beragama Islam, dipandang berat sebelah dan jauh dari pandangan hukum islam.

Untuk melengkapi sistem perbankan syariah yang dapat mengakomodir kebutuhan ummat dimana sebagian besar masyarakat Indonesia beragama Islam, maka berdirilah lembaga keuangan syariah yang disebut dengan Baitul Maal wa Tamwil, dengan fungsi utama menjalankan fungsi ekonomi kemasyarakatan berdasarkan syariah islam. Kegiatan Baitul Maal wa Tamwil adalah pengembangan usaha-usaha produktif dan investasi dalam meningkatkan kualitas kegiatan ekonomi pengusaha kecil diantaranya dengan mendorong kegiatan menabung dan menunjang kegiatan ekonominya dengan sistem Syari'ah. (Alim, 2012)

Banyaknya permintaan pembiayaan pada Baitul maal wa tamwil untuk menambah modal usaha, tentu saja tidak semua dapat berjalan lancar. Pada saat usaha terasa sepi, maka hal ini dapat berdampak pada kekuatan debitur dalam membayar angsuran pembiayaan, jika hal ini terjadi sekali, bisa jadi hanya akan mendapat surat peringatan dari pihak kreditur. Namun jika hal ini berulang hingga tiga kali dan pihak kreditur merasa tidak ada itikad baik dari debitur, maka akan 
dilaksanakan eksekusi terhadap barang jaminan pembiayaan yang bermasalah tersebut.

\section{B. Metode Penelitian}

Metode penelitian yang digunakan adalah yuridis empiris, dengan spesifikasi penelitiannya secara deskriptif analitis. Sumber dan jenis datanya berupa data primer dan data sekunder, lalu teknik pengumpulan data diperoleh melalui studi lapangan dan studi kepustakaan. Teknik analisa datanya menggunakan analisis kualitatif.

\section{Hasil dan Pembahasan}

\section{Eksekusi Jaminan Fidusia Pada Baitul wa Maal Tamwil Bina Usaha}

Berdasarkan wawancara dengan bapak Juwanto selaku Kepala Bagian Pemasaran Baitul Maal wa Tamwil Bina Usaha, didapatkan hasil wawancara tentang eksekusi jaminan fidusia pada Baitul Maal wa Tamwil Bina Usaha sebagai berikut:

Jika ada pembiayaan (dengan fidusia) yang bermasalah, solusi yang dilakukan oleh BMT adalah sebagai berikut, bahwa fidusia di BMT ini tidak didaftarkan di KJF, untuk plafon Rp 25.000.000,- keatas dahulu diaktakan notaris, sekarang Rp 10.000.000,- keatas sudah diaktakan di notaris. Karena tidak didaftarkan, maka akan dibuat surat kuasa dari pemberi fidusia kepada penerima fidusia untuk dapat sewaktu-waktu dapat mendaftarkan fidusia jika pembayaran pembiayaan mulai macet. Untuk pembiayaan dibawah itu tidak diaktakan atau dibawah tangan, walaupun tahu bahwa kekuatan hukumnya tidak kuat. Tidak didaftarkan karena biaya pembuatan akta dan pendaftran fidusia tergolong mahal, berkisar Rp 350.000,-, maka jika anggota mengajukan pembiayaan sebesar Rp 2.000.000,- akan dipotong biaya administrasi BMT dan biaya akta fidusia yang nilainya cukup besar. Selain itu, alasan tidak didaftarkan karena biasanya nominal pembiayaan tidak besar, maka tingkat kemacetan pembiayaan kecil. 
Ada kasus yang terjadi, sepeda motor yang dijaminkan di BMT Bina Usaha (Honda BEAT) justru digadaikan oleh pemberi fidusia, maka upaya yang dilakukan oleh BMT adalah memberikan solusi untuk ditebus dahulu oleh pemberi fidusia atau jika terpaksa sekali, maka yang menebus adalah BMT Bina Usaha. Namun dalam kejadian ini, sepeda motor tersebut justru ditebus oleh Ayah dari pemberi fidusia, dan beliau memberikan sepeda motor lain dengan merk MIO (bukan yang dibebani fidusia) kepada BMT untuk dibawa. Hanya saja, selang sehari pembiayaan yang bermasalah tersebut dilunasi.

Kemudian, untuk kasus Sepeda Motor hilang, ada pemberi fidusia yang tetap mengangsur kekurangannya, hal ini menunjukkan itikad baik dari debitor. Namun ada juga yang jadi sama sekali tidak mengangsur karena beranggapan barang sudah hilang, maka dirasa tidak perlu untuk mengangsur sisanya. Jika hal ini terjadi, maka dilakukan penghapusan oleh BMT Bina Usaha saat sudah jatuh tempo melalui mekanisme cadangan pembiayaan bermasalah sebesar total $2 \%$ dari pemasukan perbulan di akhir tahun, hal ini adalah solusi terakhir. Meskipun sudah dihapuskan, namun oleh BMT Bina Usaha tetap diusahakan untuk tetap ditagih.

Dalam kasus melarikan diri atau pindah alamat, data diri debitor pada saat mengajukan pembiayaan sangat penting, karena akan meringankan kerja dari petugas BMT untuk menelusuri keberadaan debitor yang melarikan diri. Ada kasus anggota yang pindah namun tidak lapor ke BMT, maka ditelusuri ternyata pindah ke temanggung, dan tetap ditagih untuk melunasi pembiayaan yang bermasalah tersebut, dan selang 2 hari, sisa hutang pembiayaan dilunasi.

Sepeda motor sebagai jaminan pembiayaan juga seringkali dipreteli, hal ini menyebabkan nilai jual menjadi turun. Solusi yang diambil oleh BMT Bina Usaha adalah, jika suku cadang yang dilepas sedikit, maka akan dicarikan pengganti dengan konsekuensi keluar uang tambahan, namun jika terlalu banyak, maka akan dijual apadanya, bahkan terkadang tidak menutupi dari pokok pembiayaan yang diambil. 
Pada kasus jaminan pembiayaan dijual tapi tidak lapor BMT, angsuran baru jalan beberapa bulan dari seharusnya empat tahun angsuran, tiba-tiba ada pihak lain yang mengangsur barang tersebut (truk) tapi atas nama debitor, kemudian pengangsur baru ini terkejut karena ternyata angsurannya banyak sekali yang telat, sehingga merasa tertipu, dan akhirnya hanya mengangsur selama 7 bulan saja. Sebenarnya truk ini akan ditarik oleh BMT, namun ternyata truk sedang berada di Sumatera sehingga tidak dapat ditarik, maka solusi yang diambil BMT adalah terus menagih kepada pengangsur yang baru, hal ini membuahkan hasil untuk beberapa bulan saja, kemudian mulai bermasalah lagi, sampai akhirnya keluar 3 kali surat peringatan.

Terkadang eksekusi yang dilakukan oleh BMT terkesan tidak maksimal, hal ini karena di BMT mengutamakan sifat kekeluargaan dibandingkan dengan cara memaksa untuk menarik barang. Pihak BMT lebih senang melakukan pendekatan secara personal, untuk memahami mengapa si anggota tidak membayar angsuran, apakah karena sedang tidak ada uang, usaha sedang sepi, atau karena ada halangan lain. Maka dari itu, terlalu banyak kelonggaran, hal ini juga dikarenakan nominal pembiayaan yang memang tidak terlalu besar jika dibandingkan dengan Bank Perkreditan Rakyat atau Bank Konvensional.

Pangsa BMT ini memang kecil, yaitu usaha mikro, seperti toko kelontong, toko material yang kecil2, usaha rumahan, jual makanan atau jajan, dll. Jadi wajar apabila nominal pembiayaan didominasi yang kecil. Sekalipun ada pembiayaan dengan nominal 300 juta rupiah, tetapi hal ini jarang. Jika ada pembiayaan bermasalah pun, terkadang hanya pokonya saja yang diambil, tidak memedulikan denda.

\section{Eksekusi Jaminan Fidusia Pada BMT KSPPS Mandiri Sejahtera}

Berdasarkan wawancara dengan bapak Andi Setyawan Suyitno, S.E. selaku Kepala Cabang KSPPS Mandiri Sejahtera, didapatkan hasil wawancara sebagai berikut: 
Pada umumnya proses eksekusi di BMT KSPPS Mandiri Sejahtera di Kabupaten Semarang melakukan pendekatan eksekusi jaminan fidusia sebagai berikut:

1) Jika ada permasalahan, dilakukan pendekatan secara kekeluargaan

2) Sangat menghindari kekerasan, misal dengan debt collector. Jika secara kekeluargaan tidak tercapai, maka penarikan kendaraan bisa dilakukan

3) Hapus buku, tetapi tidak hapus tagih.

4) Hapus buku, hapus tagih (biasa dikondisi bangkrut tetapi yang bersangkutan ada niat untuk membayar)

5) Untuk kasus seperti jaminan hilang, Kasus Melarikan Diri/ Pindah Alamat, dalam kasus ini data diri pada saat mengajukan pembiayaan sangat penting, karena dapat ditelusuri. Ada kasus anggota yang pindah namun tidak lapor ke BMT.

6) Dipreteli, hal ini menyebabkan nilai jual menjadi turun. Solusi yang diambil oleh BMT Bina Usaha adalah, jika part-part yang dilepas sedikit, maka akan dicarikan pengganti dengan konsekuensi keluar uang tambahan, namun jika terlalu banyak ya dijual apa adanya, bahkan terkadang tidak menutupi dari pokok pembiayaan yang diambil

7) Terkadang eksekusi yang dilakukan oleh BMT terkesan tidak maksimal, hal ini karena di BMT mengutamakan sifat kekeluargaan dibandingkan dengan cara memaksa untuk menarik barang. Pihak BMT lebih senang melakukan pendekatan secara personal, untuk memahami mengapa si anggota tidak membayar angsuran, apakah karena sedang tidak ada uang, usaha sedang sepi, atau karena ada halangan lain.

8) Kurangnya pemahaman anggota terhadap isi klausula jaminan

9) Untuk menjamin pembayaran dari pinjaman yang diberikan, debitor diminta untuk menyerahkan jaminan kepada bank, dimana jaminan tersebut akan diikat sebagaimana yang diatur dalam peraturan perundang-undangan. 
Prakteknya lembaga BMT di kabupaten Semarang, lebih menyukai penjualan dibawah tangan yang dilakukan oleh kreditor sendiri, karena pihak kreditor beranggapan bahwa kreditor telah menyediakan barang bergerak yang diminta konsumen (semisal motor atau mesin industri), kemudian diatasnamakan konsumen sebagai debitor (penerima kredit/pinjaman), konsekuensinya debitor menyerahkan kepada kreditor (pemberi kredit) secara fidusia, artinya debitor sebagai pemilik atas nama barang menjadi pemberi fidusia kepada kreditor yang dalam posisi sebagai penerima fidusia.

Praktek sederhana dalam jaminan fidusia adalah debitor atau pihak yang memiliki barang mengajukan pembiayaan kepada kreditor, lalu kedua belah sama-sama sepakat mengunakan jaminan fidusia terhadap benda milik debitor dan dibuatkan akta notaris lalu didaftarkan secara daring melalui website fidusia.ahu.go.id.

Fakta di lapangan menunjukan, BMT dan perbankan di kabupaten Semarang dalam melakukan perjanjian pembiayaan mencamtumkan kata-kata dijaminkan secara fidusia, akan tetapi ironisnya tidak dibuat dalam akta notaris dan tidak didaftarkan secara daring, akta semacam itu dapat disebut akta jaminan fidusia di bawah tangan.

Jika penerima fidusia mengalami kesulitan di lapangan, maka ia dapat meminta pengadilan setempat melalui juru sita membuat surat penetapan permohonan bantuan pengamanan eksekusi, bantuan pengamanan eksekusi ini bisa ditujukan kepada aparat kepolisian, pamong praja dan pamong desa atau kelurahan dimana benda objek jaminan fidusia berada, dengan demikian bahwa pembuatan sertifikat jaminan fidusia melindungi penerima fidusia. Akibat Hukum Jaminan fidusia yang tidak didaftarkan, akan menimbulkan akibat hukum yang komplek dan beresiko, kreditor bisa melakukan hak eksekusinya karena dianggap sepihak dan dapat menimbulkan kesewenang-wenangan dari kreditor. 
Lembaga pembiayaan yang tidak mendaftarkan jaminan fidusia sebenarnya akan merugikan dirinya sendiri, karena tidak punya hak eksekutorial yang legal, permasalahan bisnis yang membutuhkan kecepatan dan customer service yang prima selalu tidak sejalan dengan logika hukum yang ada, mungkin karena kekosongan hukum atau hukum yang tidak selalu secepat perkembangan zaman.

Saat ini banyak lembaga pembiayaan melakukan eksekusi pada objek barang yang dibebani jaminan fidusia yang tidak didaftarkan, bisa bernama remedial, rof coll, atau remove. Selama ini perusahaan pembiayaan merasa tindakan mereka aman dan lancar saja, hal ini terjadi karena masih lemahnya daya tawar anggota terhadap kreditor sebagai pemilik dana, ditambah lagi pengetahuan hukum masyarakat yang masih rendah. Kelemahan ini termanfaatkan oleh pelaku bisnis industri keuangan, khususnya sektor lembaga pembiayaan dan bank yang menjalankan praktek jaminan fidusia dengan akta di bawah tangan.

\section{Simpulan}

Pelaksanaan eksekusi objek jaminan fidusia yang dilakukan oleh BMT di kabupaten Semarang, sebagian besar telah memenuhi ketentuan yang diatur dalam Undang-undang Nomor 42 Tahun 1999 Tentang Fidusia. Hanya saja memang tidak semua pembiayaan dengan fidusia didaftarkan, mengingat nominal pembiayaan yang tidak besar dan biaya yang dikeluarkan untuk mendaftarkan tergolong mahal, dan kemungkinan untuk pembiayaan tersebut bermasalah adalah kecil. Pelaksanaan eksekusi objek jaminan fidusia yang berupa kendaraan bermotor dilakukan dengan cara bertahap sesuai dengan kondisi dan karakter angota atau debitor dilapangan, dimana apabila musyawarah untuk mufakat dapat dilaksanakan dengan baik antara debitor dan kreditor, maka pelaksanaan eksekusi objek jaminan dapat dilakukan dengan penjualan dibawah tangan atas kesepakatan debitor dan kreditor. 


\section{DAFTAR PUSTAKA}

Fuady, Munir. 2013. Hukum Jaminan Utang. Jakarta : Erlangga.

Subekti, R. 2008. Hukum Perjanjian. Jakarta: Intermasa.

Waluyo, Bambang. 2002. Penelitian Hukum Dalam Praktek. Jakarta: Sinar Grafika.

Muh. Hafidzun Alim, 2012, Pengertian BMT, http://wahdah.or.id/sekilas-tentangbaitul-maal-wat-tamwil-bmt/ 